\title{
Monitoring 2019 Forest Fires in Southeastern Australia with GNSS Technique
}

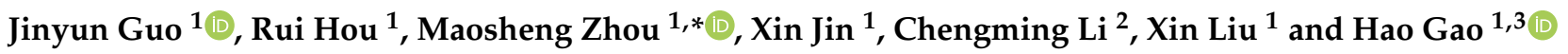 \\ 1 College of Geodesy and Geomatics, Shandong University of Science and Technology, Qingdao 266590, China; \\ guojy@sdust.edu.cn (J.G.); hourui@sdust.edu.cn (R.H.); skdjinxin1010@sdust.edu.cn (X.J.); \\ skd994268@sdust.edu.cn (X.L.); gaohao88_sdioi@qlu.edu.cn (H.G.) \\ 2 Chinese Academy of Surveying and Mapping, Beijing 100036, China; cmli@casm.ac.cn \\ 3 Institute of Oceanographic Instrumentation, Qilu University of Technology (Shandong Academy of Sciences), \\ Qingdao 266061, China \\ * Correspondence: zhoumaosheng2018@sdust.edu.cn
}

check for updates

Citation: Guo, J.; Hou, R.; Zhou, M.; Jin, X.; Li, C.; Liu, X.; Gao, H.

Monitoring 2019 Forest Fires in

Southeastern Australia with GNSS

Technique. Remote Sens. 2021, 13, 386

https://doi.org/10.3390/rs13030386

Received: 29 December 2020

Accepted: 20 January 2021

Published: 22 January 2021

Publisher's Note: MDPI stays neutral with regard to jurisdictional claims in published maps and institutional affiliations.

Copyright: (C) 2021 by the authors Licensee MDPI, Basel, Switzerland. This article is an open access article distributed under the terms and conditions of the Creative Commons Attribution (CC BY) license (https:// creativecommons.org/licenses/by/ $4.0 /)$

\begin{abstract}
From late 2019 to early 2020, forest fires in southeastern Australia caused huge economic losses and huge environmental pollution. Monitoring forest fires has become increasingly important. A new method of fire detection using the difference between global navigation satellite system (GNSS)-derived precipitable water vapor and radiosonde-derived precipitable water vapor $(\triangle \mathrm{PWV})$ is proposed. To study the feasibility of the new method, the relationship is studied between particulate matter 10 (PM10) (2.5 to 10 microns particulate matter) and $\triangle \mathrm{PWV}$ based on Global Positioning System (GPS) data, radiosonde data, and PM10 data from 1 June 2019 to 1 June 2020 in southeastern Australia. The results show that before the forest fire, $\triangle \mathrm{PWV}$ and PM10 were smaller and less fluctuating. When the forest fire happened, $\triangle \mathrm{PWV}$ and PM10 were increasing. Then after the forest fire, PM10 became small with relatively smooth fluctuations, but $\triangle \mathrm{PWV}$ was larger and more fluctuating. Correlation between the 15-day moving standard deviation (STD) time series of $\triangle \mathrm{PWV}$ and PM10 after the fire was significantly higher than that before the fire. This study shows that $\triangle \mathrm{PWV}$ is effective in monitoring forest fires based on GNSS technique before and during forest fires in climates with more uniform precipitation, and using $\triangle \mathrm{PWV}$ to detect forest fires based on GNSS needs to be further investigated in climates with more precipitation and severe climate change.
\end{abstract}

Keywords: Australian forest fires; global navigation satellite system (GNSS); precipitable water vapor (PWV); PM10; radiosonde

\section{Introduction}

The Gospers fire breaking out in Australia at the end of 2019 is thought to be the largest point-of-ignition fire in Australian history, with the total burned area approaching 6 million hectares [1]. This is almost seven times the size of the area burned in 2019 in the Amazon [2]. Fires not only cause significant economic losses but also produce large amounts of smoke and soot during the burning process and lead to significant ecological losses [3], making it increasingly important to study how to detect forest fires. Forests are the protector of the earth, and forest fires generally happen in remote areas [4], often caused by human activities, such as smoking and barbecuing. Temperature, wind speed, and vegetation type are determined to be the major driving factors. Solar radiation had the most influence on the spatial pattern of fire occurrence, and climate variables were the dominant factors for the density of fire occurrence [5]. The earlier fire is detected, the less damage there is [6]. Forest fire monitoring methods are constantly being updated and becoming more and more flexible. Drones and remote sensing have been used to quickly monitor fires [7]. Optical smoke detectors, electronic radar monitoring system, automatic monitoring system, and other monitoring systems have been developed to monitor forest fires [8]. Zhang et al. [9] developed the machine-vision-based watchtower system to replace 
the human-vision-based watchtower systems to monitor forest fires. Yin et al. [10] used remote sensing and various meteorological datasets to analyze the impact of the forest fires in 2015 in Sumatra on the atmospheric environment and analyze changes in various pollutants. Melo et al. [11] used airborne laser scanning to monitor the occurrence of fires in eucalyptus plantations. The environmental impacts of forest fires and the link between forest fire and species extinction in Australia from late 2019 to early 2020 have been studied [12]. Nowadays, the monitoring of forest fires mainly uses various smoke and fire sensors or remote sensing, but these methods have the shortcomings of poor real-time response, high cost, and huge investment in human and material resources [13]. Additionally, research studies on forest fires in Australia have focused on the effect of changes in biological species due to forest fire.

Fires produce large amounts of smoke particles, among which particulate matter 10 (PM10) (2.5 to 10 microns particulate matter) and particulate matter 2.5 (PM2.5) (2.5 microns or less particulate matter) are two important indicators of fire pollution. PM2.5 and PM10 consist of a variety of toxic and hazardous substances that can be breathed directly into the lungs and cause respiratory diseases, such as asthma and cardiovascular diseases [14,15]. Therefore, they are commonly used to monitor forest fires and research the impact of forest fire on the environment. Augusto et al. [16] evaluated the effect of PM10 on mortality due to the forest fires in Portugal hit by Storm Ophelia, and concluded that PM10 from forest fires significantly increases the number of cardiopulmonary-related deaths. Sánchez-Balseca et al. [17] developed dynamic linear models of PM2.5 and PM10 as parameters for studying fires and modeling the exposure levels of PM2.5 before and after fires. Guo et al. [18] conducted a study on forest fires in northern China to assess the impact of changes in PM2.5 on environmental pollution. Guo et al. [19] used the global navigation satellite system (GNSS) for short-term prediction of PM2.5, demonstrating the feasibility of monitoring of particulate matter with GNSS technique. Based on the GNSS and meteorological factors, Wen et al. [20] verified the relationship between zenith wet delay (ZWD) and PM2.5, and forecast PM10 values in the short term. Therefore, it is possible to monitor forest fires based on GNSS technique.

Precipitable water vapor (PWV) is an important component of the atmosphere and one of the most active parameters in the atmospheric composition [21], with its content in the atmosphere varying dramatically over time and space [22-24]. Atmospheric precipitation also affects PWV [25]. It is widely used in the field of atmospheric activity [26-28]. PWV inversed by GNSS data has been validated with the same accuracy as conventional techniques, such as radiosonde, airborne radiometer, water vapor radiometer, and lidar [29-31]. GNSS-derived PWV has the advantages of low cost and high temporal and spatial resolutions [32,33].

GNSS-derived PWV is calculated by GNSS-derived ZWD, which is affected by both particles and water vapor. The PWV obtained by a radiosonde station is only caused by water vapor. The difference between GNSS-derived precipitable water vapor and radiosonde-derived precipitable water vapor $(\triangle \mathrm{PWV})$ may be caused by particulate matter. Using $\triangle \mathrm{PWV}$ to detect forest fire is feasible in theory. The purpose of this study is to verify the feasibility of monitoring forest fires based on GNSS technique. The GNSS data and radiosonde data of the forest fire area in southeastern Australia are processed to obtain $\triangle \mathrm{PWV}$. The relationship between $\triangle \mathrm{PWV}$ and PM10 is analyzed to verify the feasibility of monitoring forest fires based on GNSS. Section 2 describes the different datasets and the methodology used in this work. Processing results and analysis are presented in Section 3. Section 4 discusses the feasibility of monitoring forest fires with GNSS technique under different climatic conditions. Finally, the conclusion is given in Section 5. 


\section{Materials and Methods}

\subsection{Materials}

\subsubsection{Study Area}

Forest fires in Australia burned up to 50 million hectares each year [34]. From late 2019 to early 2020, a huge forest fire, known as the "Black Summer Bushfires," broke out in southeastern Australia [35], causing tremendous economic loss and environmental damage.

The study area is shown in Figure 1. The climate types here are mainly humid subtropical climate, temperate marine climate, and Mediterranean climate [36]. The eastern coastal region between $25^{\circ} \mathrm{S}$ and $35^{\circ} \mathrm{S}$ in southeastern Australia, which is located on the eastern windward slope of the Great Dividing Range, has a humid subtropical climate [37]. Under the influence of the differences in thermophysical properties of land and sea, the southeast monsoon blows in the summer with large precipitation, while the opposite occurs in the winter. Southeastern Australia between $35^{\circ} \mathrm{S}$ and $45^{\circ} \mathrm{S}$, which is located at midlatitudes, has a temperate marine climate [38]. The region, influenced by westerly winds at midlatitudes all year round, is mild and humid all year round. The region between $32^{\circ} \mathrm{S}$ to $40^{\circ} \mathrm{S}$ and $133^{\circ} \mathrm{E}$ to $140^{\circ} \mathrm{E}$ has a Mediterranean climate [39], controlled by alternating subtropical high-pressure belts and westerly winds.

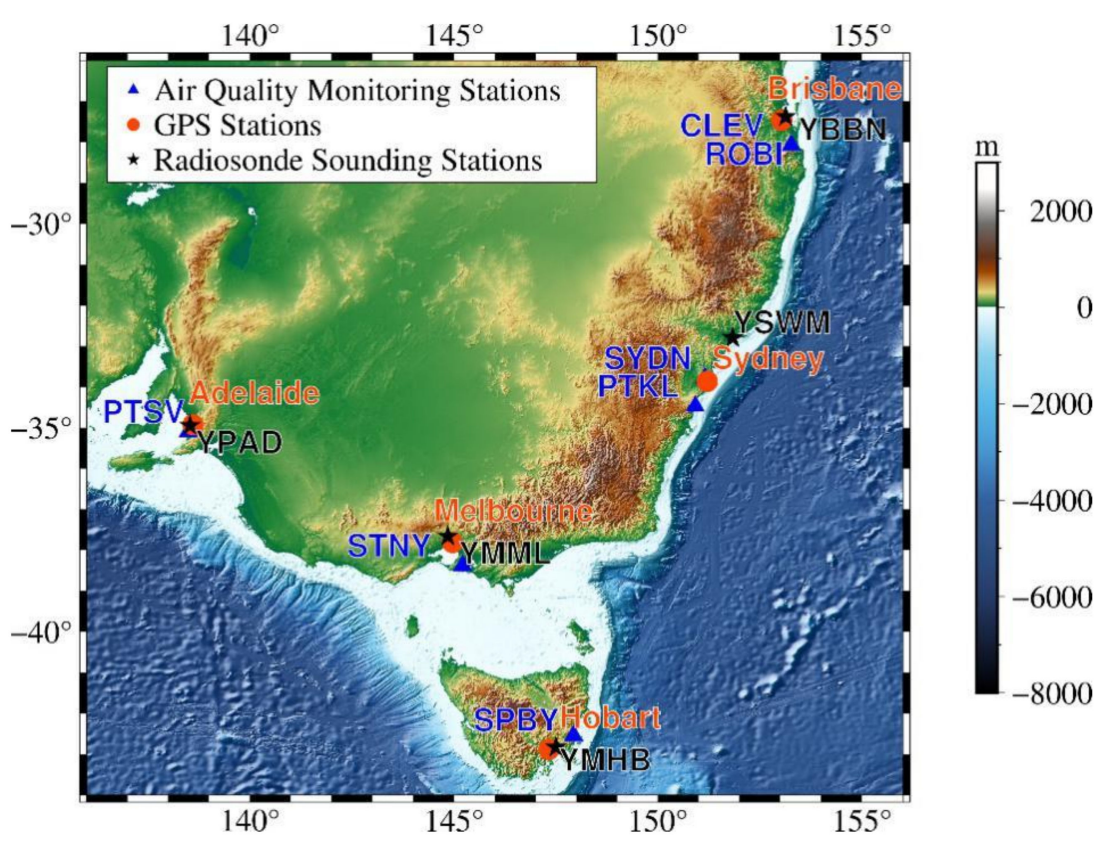

Figure 1. Geographical distribution of global navigation satellite system (GNSS) stations, radiosonde stations, and air quality monitoring stations.

\subsubsection{Data}

The continuous GNSS data at seven stations in southeastern Australia (see Figure 1), released by Système d'Observation du Niveau des Eaux Littorales (SONEL) (http://www. sonel.org), are used [40]. The receivers provide the Global Positioning System (GPS) data at a $30 \mathrm{~s}$ sampling rate and contain $24 \mathrm{~h}$ of data. The GPS data from 1 June 2019 to 1 June 2020 are processed using GAMIT/GLOBK 10.71. The GPS data at SPBY is only available until 7 February 2020 (before and during the forest fire), and the GPS data at STNY are lacking from 30 November 2019 to 27 December 2019. Among those GNSS stations, ROBI, CLEV, PTKL, and SYDN have a humid subtropical climate; STNY and SPBY have a temperate maritime climate; and PTSV has a Mediterranean climate. GNSS stations, radiosonde stations, and air quality monitoring stations are mainly located in the southeast coastal region, and their distribution is shown in Figure 1. 
Radiosonde-PWV data at five radiosonde stations (http:/ / weather.uwyo.edu/upperair/ sounding.html) are selected. YBBN and YSWM stations make one observation per day at 0:00 UTC, while YPAD, YMML, and YMHB make two observations per day at 0:00 and 12:00 UTC. The PWV data from 1 June 2019 to 1 June 2020 are used.

Five air quality monitoring stations are selected to provide data of PM2.5 and PM10 (https://aqicn.org/data-platform/register/). Air quality monitoring data from 1 June 2019 to 1 June 2020 are processed.

The information and geographical distribution of GNSS stations, radiosonde stations, and air quality monitoring stations are shown in Table 1 and Figure 1, respectively.

Table 1. Information of GNSS stations, radiosonde stations, and air quality monitoring stations.

\begin{tabular}{|c|c|c|c|c|c|c|c|c|}
\hline $\begin{array}{l}\text { GNSS } \\
\text { Stations }\end{array}$ & Longitude & Latitude & $\begin{array}{l}\text { Radiosonde } \\
\text { Stations }\end{array}$ & Longitude & Latitude & $\begin{array}{l}\text { Air Quality } \\
\text { Monitoring } \\
\text { Stations }\end{array}$ & Longitude & Latitude \\
\hline $\begin{array}{l}\text { CLEV } \\
\text { ROBI }\end{array}$ & $\begin{array}{l}153.26^{\circ} \mathrm{E} \\
153.38^{\circ} \mathrm{E}\end{array}$ & $\begin{array}{l}28.07^{\circ} \mathrm{S} \\
28.07^{\circ} \mathrm{S}\end{array}$ & YBBN & $153.13^{\circ} \mathrm{E}$ & $27.38^{\circ} \mathrm{S}$ & Brisbane & $153.02^{\circ} \mathrm{E}$ & $27.46^{\circ} \mathrm{S}$ \\
\hline $\begin{array}{l}\text { PTKL } \\
\text { SYDN }\end{array}$ & $\begin{array}{l}150.91^{\circ} \mathrm{E} \\
151.15^{\circ} \mathrm{E}\end{array}$ & $\begin{array}{l}34.47^{\circ} \mathrm{S} \\
33.78^{\circ} \mathrm{S} \\
\end{array}$ & YSWM & $151.83^{\circ} \mathrm{E}$ & $32.80^{\circ} \mathrm{S}$ & Sydney & $151.21^{\circ} \mathrm{E}$ & $33.86^{\circ} \mathrm{S}$ \\
\hline PTSV & $138.48^{\circ} \mathrm{E}$ & $35.09^{\circ} \mathrm{S}$ & YPAD & $138.53^{\circ} \mathrm{E}$ & $34.95^{\circ} \mathrm{S}$ & Adelaide & $138.59^{\circ} \mathrm{E}$ & $34.92^{\circ} \mathrm{S}$ \\
\hline STNY & $145.21^{\circ} \mathrm{E}$ & $38.37^{\circ} \mathrm{S}$ & YMML & $144.85^{\circ} \mathrm{E}$ & $37.66^{\circ} \mathrm{S}$ & Melbourne & $144.96^{\circ} \mathrm{E}$ & $37.81^{\circ} \mathrm{S}$ \\
\hline SPBY & $147.93^{\circ} \mathrm{E}$ & $42.54^{\circ} \mathrm{S}$ & YMHB & $147.50^{\circ} \mathrm{E}$ & $42.83^{\circ} \mathrm{S}$ & Hobart & $147.32^{\circ} \mathrm{E}$ & $42.87^{\circ} \mathrm{S}$ \\
\hline
\end{tabular}

Both the CLEV and ROBI stations are adjacent to the YBBN and Brisbane stations. Therefore, the CLEV and ROBI stations and the YBBN and Brisbane stations are analyzed as a group. SYDN and PTKL are adjacent to YSWM and Sydney. Therefore, SYDN and PTKL and YSWM and Sydney are analyzed as group. PTSV, YPAD, and Adelaide are a group. STNY, YMML, and Melbourne are a group. SPBY, YMHB, and Hobart are a group. Details of the grouping are listed in Table 1.

The forest fire information released by the National Aeronautics and Space Administration (NASA) (https: / / firms.modaps.eosdis.nasa.gov/map/) is listed in Table 2. Taking the GNSS station as the center, the time of forest fire, intensity of forest fire, and location of forest fire are obtained. This information is also listed in Table 2.

Table 2. Forest fire information statistics near GNSS stations.

\begin{tabular}{ccccc}
\hline Name & Time & Status & Longitude & Latitude \\
\hline \multirow{5}{*}{ CLEV ROBI } & August & Western Sporadic Fire & $152.836^{\circ} \mathrm{E}$ & $28.428^{\circ} \mathrm{S}$ \\
& September & Northwest Large fire & $153.017^{\circ} \mathrm{E}$ & $28.161^{\circ} \mathrm{S}$ \\
& November & Western Blockbuster Fire & $152.691^{\circ} \mathrm{E}$ & $28.304^{\circ} \mathrm{S}$ \\
& December & Southern Blockbuster Fire & $153.162^{\circ} \mathrm{E}$ & $29.105^{\circ} \mathrm{S}$ \\
& Southwest Blockbuster Fire & $153.054^{\circ} \mathrm{E}$ & $28.134^{\circ} \mathrm{S}$ \\
\hline \multirow{2}{*}{ PTKL SYDN } & November & Northwest Sporadic Fire & $150.614^{\circ} \mathrm{E}$ & $34.818^{\circ} \mathrm{S}$ \\
& December & Northwest Blockbuster Fire & $152.229^{\circ} \mathrm{E}$ & $34.052^{\circ} \mathrm{S}$ \\
& & Southwest Blockbuster Fire & $150.526^{\circ} \mathrm{E}$ & $34.342^{\circ} \mathrm{S}$ \\
& January & Southwest Large fire & $150.399^{\circ} \mathrm{E}$ & $34.365^{\circ} \mathrm{S}$ \\
& & South Large fire & $150.466^{\circ} \mathrm{E}$ & $34.746^{\circ} \mathrm{S}$ \\
\hline \multirow{2}{*}{ PTSV } & December & Eastern Sporadic Fire & $138.901^{\circ} \mathrm{E}$ & $34.898^{\circ} \mathrm{S}$ \\
& January & Western Large fire & $137.346^{\circ} \mathrm{E}$ & $35.683^{\circ} \mathrm{S}$ \\
\hline
\end{tabular}


Table 2. Cont.

\begin{tabular}{ccccc}
\hline Name & Time & Status & Longitude & Latitude \\
\hline \multirow{4}{*}{ STNY } & November & Eastern Sporadic Fire & $147.891^{\circ} \mathrm{E}$ & $37.629^{\circ} \mathrm{S}$ \\
& December & Eastern Blockbuster Fire & $147.547^{\circ} \mathrm{E}$ & $37.572^{\circ} \mathrm{S}$ \\
& January & Eastern Blockbuster Fire & $147.677^{\circ} \mathrm{E}$ & $37.686^{\circ} \mathrm{S}$ \\
& February & Eastern Blockbuster Fire & $147.677^{\circ} \mathrm{E}$ & $37.686^{\circ} \mathrm{S}$ \\
& March & Western Sporadic Fire & $143.942^{\circ} \mathrm{E}$ & $38.019^{\circ} \mathrm{S}$ \\
\hline \multirow{2}{*}{ SPBY } & November & Northern Sporadic Fire & $147.916^{\circ} \mathrm{E}$ & $41.476^{\circ} \mathrm{S}$ \\
& December & Northern Large fire & $147.941^{\circ} \mathrm{E}$ & $42.133^{\circ} \mathrm{S}$ \\
& January & Northeast Sporadic Fire & $148.011^{\circ} \mathrm{E}$ & $41.711^{\circ} \mathrm{S}$ \\
\hline
\end{tabular}

\subsection{Methodology}

\subsubsection{PWV Inversion Based on GNSS Data}

The GNSS phase observation equation is [41,42]

$$
L_{i, f}^{j}=\rho_{i}^{j}+c\left(d t_{i}-d t^{j}\right)+M \cdot Z T D-I_{i, f}^{j}+\lambda_{f} N_{i, f}^{j}+\varepsilon_{i, f^{j}}^{j}
$$

where $f$ denotes signal frequency, $\rho_{i}^{j}$ is the geometry distance from receiver $i$ to satellite $j$, $c$ is the speed of light in vacuum, $d t_{i}$ is the receiver $i$ clock offset, $d t^{j}$ is the satellite $j$ clock offset, and $M$ is the troposphere mapping function. $I_{i, f}^{j}$ is the slant ionosphere delay. $\lambda_{f}$ is the wavelength of phase observation at frequency $f$. $N_{i, f}^{j}$ is the phase ambiguity that is not integer since it includes the receiver and satellite initial phase biases. $\varepsilon_{i, f}^{j}$ contains other unmodelled errors for phase observation. The zenith total delay (ZTD) as unknown parameters is estimated [20], and the zenith hydrostatic delay (ZHD) is calculated using the Saastamoinen (SAAS) model $[43,44]$. The equation is

$$
Z H D=\frac{0.0022768 \cdot P}{1-0.00266 \cdot \operatorname{COS}(2 L)-0.00028 \cdot H^{\prime}}
$$

where $P, L$, and $H$ are the GNSS station's atmospheric pressure, latitude, and height, respectively. Finally, ZTD is subtracted from ZHD to obtain ZWD, and then PWV $\mathrm{GNSS}_{\text {can }}$ be obtained from the empirical Equation (3) $[45,46]$, that is,

$$
\begin{gathered}
P W V_{G N S S}=Z W D \cdot \pi, \\
\pi=\frac{10^{6}}{\rho_{W} \cdot g_{s} \cdot\left(k_{2}+\left(\frac{k_{3}}{T_{m}}\right)\right)}
\end{gathered}
$$

where $\pi$ is the conversion factor, $g_{s}=461 \mathrm{Jkg}^{-1} \mathrm{~K}^{-1}$ is a constant, $\rho_{w}$ is the density of liquid water; $k_{2}=16.48 \mathrm{~K} \cdot \mathrm{hPa}^{-1}$ is a constant, $k_{3}=(3.776 \pm 0.014) * 10^{5} \mathrm{~K}^{2} \mathrm{hPa}^{-1}$ is a constant, and $T_{m}$ is the weighted average temperature of the troposphere.

\subsubsection{PWV Inversion Based on Radiosonde Data}

PWV can also be measured by radiosonde stations. First, the precipitable water pressure is calculated using the relative humidity and the pressure of saturated water vapor. Then the specific humidity is obtained from the precipitable water pressure. Finally, the $\mathrm{PWV}$ inversion based on radiosonde data $\left(\mathrm{PWV}_{\mathrm{RAD}}\right)$ is calculated with specific humidity, atmospheric pressure, and the earth gravity accelerator [47].

The precipitable water pressure (e) is calculated from the relative humidity (U) and the saturated water vapor pressure (E) of the radiosonde data, that is,

$$
e=\frac{U \cdot E}{100}
$$


The specific humidity $(q)$ is then obtained by

$$
q=\frac{\sigma \cdot \mathrm{e}}{p-\mathrm{e} \cdot(1-\sigma)}
$$

where $\sigma=0.622 \mathrm{~g} \cdot \mathrm{kg}^{-1}$ is a constant.

The $\mathrm{PWV}_{\mathrm{RAD}}$ is calculated by

$$
P W V_{R A D}=\frac{1}{g} \int_{p_{t}}^{p_{s}} q d p,
$$

where $p_{t}$ and $p_{s}$ are the atmospheric pressures at the ground surface and stratosphere, respectively, and $g$ is the earth gravity accelerator.

\subsubsection{Monitoring Forest Fires with $\triangle \mathrm{PWV}$}

The equation of $\triangle \mathrm{PWV}$ is

$$
\triangle P W V=P W V_{G N S S}-P W V_{R A D},
$$

ZTD contains the influence of particulate matter. ZHD is calculated by the SAAS model, which reflects the delay caused by the standard dry atmosphere. Therefore, the delay caused by particulate matter will be included in ZWD, which will also affect PWV. $\mathrm{PWV}_{\mathrm{RAD}}$ is calculated directly from the radiosonde data, and its obtained value is not affected by particulate matter. Therefore, $\triangle \mathrm{PWV}$ is affected by particulate matter. Fires will produce a lot of PM10, PM2.5, and other dense smoke particulate pollutants. Therefore, the relationship between $\triangle \mathrm{PWV}$ and PM10 can be used to monitor the occurrence of forest fires.

The radiosonde stations of YBBN and YSWM only observe at 0:00 UTC and PM10, providing the average of daily observations. Therefore, the 0:00 radiosonde-derived PWV data and GNSS-derived PWV data at 0:00 are selected. According to the grouping in Table 1 and Equation (8), $\triangle \mathrm{PWV}$ is obtained. The relationship between $\triangle \mathrm{PWV}$ and PM10/PM2.5 before and after fire is analyzed to study the feasibility of using GNSS to detect forest fire.

\section{Result and Analysis}

To study the feasibility of monitoring forest fire using the $\triangle \mathrm{PWV}$ technique, the paper

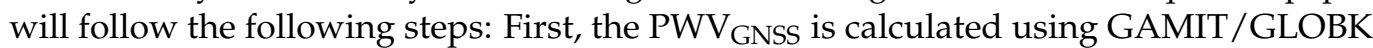
10.71. $\mathrm{PWV}_{\mathrm{GNSS}}$ is obtained using GPS phase observations. $\mathrm{PWV}_{\mathrm{GNSS}}$ data are taken every $2 \mathrm{~h}$. We take an average of $12 \mathrm{PWV}$ data every day to get the PWV of a single day. Second, $\triangle \mathrm{PWV}$ is calculated by Equation (8). Third, the relationship between $\Delta \mathrm{PWV}$ and PM2.5/PM10 is analyzed to verify the feasibility of monitoring forest fires using the $\triangle \mathrm{PWV}$ technique.

\subsection{Correlation between PM2.5 and PM10}

Forest fires produce a large number of dense smoke particles. PM2.5 and PM10, as two important forest fire pollutants, are commonly used in forest fire monitoring studies. The correlation between PM2.5 and PM10 before, during, and after forest fires is counted. Then the mean (MEAN), maximum (MAX), and standard deviation (STD) of PM2.5 and PM10 before, during, and after forest fires are analyzed. The results are listed in Table 3.

It is found that the correlation coefficient between PM2.5 and PM10 is greater than 0.85 at the five air quality monitoring stations. The MAX, MEAN, and STD of PM2.5 and PM10 are largest during the forest fire. In Brisbane, Sydney, and Melbourne, the MAX, MEAN, and STD of PM2.5 before the fire are larger than those after the fire. In Adelaide, the MAX, MEAN, and STD of PM2.5 after the forest fire are larger than those before the fire. In Brisbane, Adelaide, Sydney, Melbourne, the MAX, MEAN, and STD of PM10 after the forest fire are larger than those before the fire. The statistical results indicate that PM10 is more consistent with the effects of forest fires. PM10 and PM2.5 are highly correlated 
and have similar sources [48]. Therefore, PM10 data are used as the comparison parameter in forest fire study.

Table 3. Correlation coefficient between particulate matter 2.5 (PM2.5) and particulate matter 10 (PM10) and index statistics of PM2.5/PM10 before, during, and after forest fire.

\begin{tabular}{|c|c|c|c|c|c|c|c|c|}
\hline \multirow{2}{*}{ Name } & \multirow{2}{*}{$\begin{array}{l}\text { Correlation } \\
\text { Coefficient }\end{array}$} & \multirow{2}{*}{ Index } & \multicolumn{3}{|c|}{ PM2.5 $\left(\mu \mathrm{g} / \mathrm{m}^{3}\right)$} & \multicolumn{3}{|c|}{$\operatorname{PM10}\left(\mu \mathrm{g} / \mathrm{m}^{3}\right)$} \\
\hline & & & Before & During & After & Before & During & After \\
\hline \multirow{3}{*}{ Brisbane } & \multirow{3}{*}{0.856} & MAX & 65.000 & 184.000 & 42.000 & 24.000 & 113.000 & 47.000 \\
\hline & & MEAN & 27.567 & 39.079 & 21.410 & 12.650 & 23.085 & 12.752 \\
\hline & & STD & 11.356 & 24.733 & 6.058 & 3.999 & 16.890 & 4.473 \\
\hline \multirow{3}{*}{ Adelaide } & \multirow{3}{*}{0.873} & MAX & 35.000 & 70.000 & 34.000 & 31.000 & 47.000 & 32.000 \\
\hline & & MEAN & 6.717 & 25.459 & 18.189 & 8.460 & 19.902 & 16.189 \\
\hline & & STD & 4.081 & 14.884 & 5.992 & 4.113 & 9.084 & 5.598 \\
\hline \multirow{3}{*}{ Sydney } & \multirow{3}{*}{0.877} & MAX & 65.000 & 156.000 & 48.000 & 26.000 & 72.000 & 28.000 \\
\hline & & MEAN & 30.408 & 42.184 & 19.849 & 14.418 & 26.041 & 14.397 \\
\hline & & STD & 12.120 & 31.587 & 8.168 & 4.745 & 16.252 & 5.241 \\
\hline \multirow{3}{*}{ Melbourne } & \multirow{3}{*}{0.876} & MAX & 74.000 & 251.000 & 50.000 & 31.000 & 141.000 & 28.000 \\
\hline & & MEAN & 24.943 & 32.723 & 23.034 & 11.953 & 19.227 & 14.034 \\
\hline & & STD & 11.099 & 32.864 & 8.165 & 4.439 & 17.557 & 5.367 \\
\hline \multirow{3}{*}{ Hobart } & \multirow{3}{*}{0.874} & MAX & 50.000 & 119.000 & & 12.000 & 45.000 & \\
\hline & & MEAN & 10.892 & 11.779 & & 4.719 & 6.600 & \\
\hline & & STD & 7.325 & 13.715 & & 2.402 & 5.813 & \\
\hline
\end{tabular}

\subsection{Analysis of Forest Fire Monitoring in Southeastern Australia Based on GNSS}

In order to verify the feasibility of monitoring forest fires in southeastern Australia based on the GNSS, the STD, MEAN, and MAX of $\triangle \mathrm{PWV}$ and PM10 during Australian forest fires are analyzed. The analyzed results are shown in Table 4 and Figures 2-6 (the fire period is in the red box). The PM10 data of the GNSS station are measured by the air quality monitoring station nearest to the GNSS station. The matching of the GNSS station and air quality monitoring station is listed in Table 2.

Table 4. The statistical results of the difference between GNSS-derived precipitable water vapor and radiosonde-derived precipitable water vapor $(\triangle \mathrm{PWV})$ and PM10 before, during, and after forest fire. The format of Time is: month/year. For example, "6/19-11/19" means from June 2019 to November 2019.

\begin{tabular}{cccccccc}
\hline \multirow{2}{*}{ Name } & \multirow{2}{*}{ Index } & \multicolumn{3}{c}{$\Delta \mathbf{P W V}(\mathbf{m m})$} & \multicolumn{3}{c}{ PM10 $\left(\boldsymbol{\mu g} / \mathbf{m}^{\mathbf{3}}\right)$} \\
\cline { 3 - 7 } & & Before & During & After & Before & During & After \\
\hline \multirow{5}{*}{ PTSV } & TIME & $6 / 19-$ & $12 / 19-$ & $3 / 20-$ & $6 / 19-$ & $12 / 19-$ & $3 / 20-$ \\
& STD & $11 / 19$ & $2 / 20$ & $5 / 20$ & $11 / 19$ & $2 / 20$ & $5 / 20$ \\
& MEAN & 0.855 & 3.378 & 2.965 & 4.113 & 9.084 & 5.598 \\
& MAX & 7.480 & 1.545 & 1.124 & 8.460 & 19.902 & 16.189 \\
& & $6 / 19-$ & $11 / 19-$ & $4 / 20-$ & $6 / 19-$ & $11 / 19-$ & $4 / 20-$ \\
\multirow{5}{*}{ STNY } & TIME & $10 / 19$ & $3 / 20$ & $5 / 20$ & $10 / 19$ & $3 / 20$ & $5 / 20$ \\
& STD & 1.706 & 2.963 & 3.906 & 4.439 & 17.557 & 5.367 \\
& MEAN & -1.000 & -0.803 & -0.624 & 11.953 & 19.227 & 14.034 \\
& MAX & 5.050 & 11.850 & 10.470 & 31.000 & 141.000 & 28.000 \\
\hline \multirow{5}{*}{ SPBY } & & $6 / 19-$ & $11 / 19-$ & & $6 / 19-$ & $11 / 19-$ & \\
& TIME & $10 / 19$ & $1 / 20$ & & $10 / 19$ & $1 / 20$ & \\
& STD & 2.768 & 4.910 & & 2.402 & 5.813 & \\
& MEAN & 0.293 & 0.860 & & 4.719 & 6.600 & \\
& MAX & 15.810 & 17.730 & & 12.000 & 45.000 & \\
\hline
\end{tabular}


Table 4. Cont.

\begin{tabular}{|c|c|c|c|c|c|c|c|}
\hline \multirow{2}{*}{ Name } & \multirow{2}{*}{ Index } & \multicolumn{3}{|c|}{$\Delta \mathrm{PWV}(\mathrm{mm})$} & \multicolumn{3}{|c|}{$\operatorname{PM10}\left(\mu \mathrm{g} / \mathrm{m}^{3}\right)$} \\
\hline & & Before & During & After & Before & During & After \\
\hline \multirow{4}{*}{ CLEV } & TIME & $\begin{array}{l}6 / 19- \\
7 / 19\end{array}$ & $\begin{array}{l}8 / 19- \\
1 / 20\end{array}$ & $\begin{array}{l}2 / 20- \\
5 / 20\end{array}$ & $\begin{array}{l}6 / 19- \\
7 / 19\end{array}$ & $\begin{array}{l}8 / 19- \\
1 / 20\end{array}$ & $\begin{array}{l}2 / 20 \\
5 / 20\end{array}$ \\
\hline & STD & 1.499 & 2.150 & 2.750 & 3.999 & 16.890 & 4.473 \\
\hline & MEAN & 0.149 & 0.227 & 0.832 & 12.650 & 23.085 & 12.752 \\
\hline & MAX & 5.200 & 7.560 & 10.460 & 24.000 & 113.000 & 47.000 \\
\hline \multirow{4}{*}{ ROBI } & TIME & $\begin{array}{l}6 / 19- \\
7 / 19\end{array}$ & $\begin{array}{l}8 / 19- \\
1 / 20\end{array}$ & $\begin{array}{l}2 / 20- \\
5 / 20\end{array}$ & $\begin{array}{l}6 / 19- \\
7 / 19\end{array}$ & $\begin{array}{l}8 / 19- \\
1 / 20\end{array}$ & $\begin{array}{l}2 / 20- \\
5 / 20\end{array}$ \\
\hline & STD & 2.924 & 2.974 & 3.682 & 3.999 & 16.890 & 4.473 \\
\hline & MEAN & -0.798 & 0.026 & 0.697 & 12.650 & 23.085 & 12.752 \\
\hline & MAX & 7.780 & 10.570 & 10.770 & 24.000 & 113.000 & 47.000 \\
\hline \multirow{4}{*}{ PTKL } & TIME & $\begin{array}{l}6 / 19- \\
9 / 19\end{array}$ & $\begin{array}{c}10 / 19- \\
2 / 20\end{array}$ & $\begin{array}{l}3 / 20- \\
5 / 20\end{array}$ & $\begin{array}{l}6 / 19- \\
19 / 9\end{array}$ & $\begin{array}{c}10 / 19- \\
2 / 20\end{array}$ & $\begin{array}{l}3 / 20- \\
5 / 20\end{array}$ \\
\hline & STD & 3.593 & 7.176 & 5.728 & 4.745 & 16.252 & 5.241 \\
\hline & MEAN & 1.687 & 3.872 & 2.523 & 14.418 & 26.041 & 14.397 \\
\hline & MAX & 12.870 & 44.150 & 30.090 & 26.000 & 72.000 & 28.000 \\
\hline \multirow{4}{*}{ SYDN } & TIME & $\begin{array}{l}6 / 19- \\
9 / 19\end{array}$ & $\begin{array}{c}10 / 19- \\
2 / 20\end{array}$ & $\begin{array}{l}3 / 20- \\
5 / 20\end{array}$ & $\begin{array}{l}6 / 19- \\
9 / 19\end{array}$ & $\begin{array}{c}10 / 19- \\
2 / 20\end{array}$ & $\begin{array}{l}3 / 20- \\
5 / 20\end{array}$ \\
\hline & STD & 2.611 & 4.958 & 5.375 & 4.745 & 16.252 & 5.241 \\
\hline & MEAN & 0.294 & 1.621 & 0.231 & 14.418 & 26.041 & 14.397 \\
\hline & MAX & 8.530 & 23.230 & 27.870 & 26.000 & 72.000 & 28.000 \\
\hline
\end{tabular}

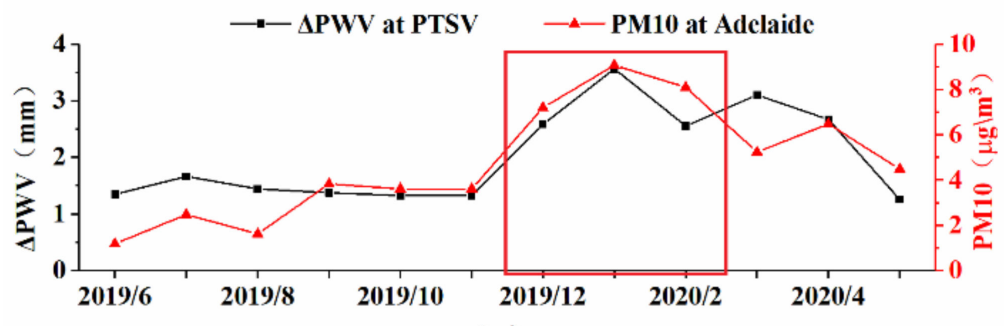

(a)
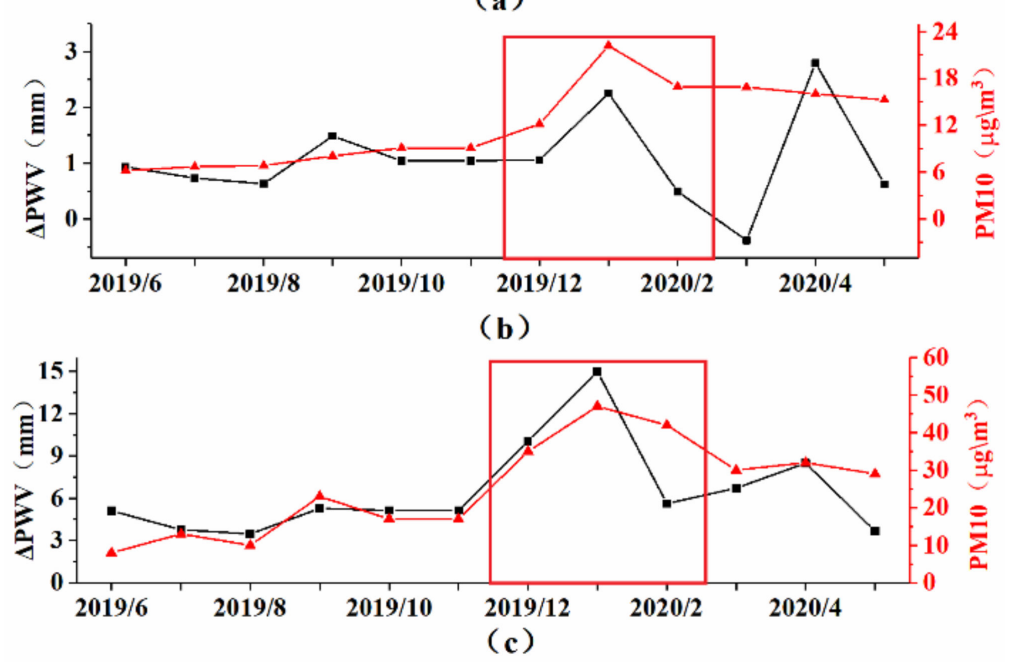

Figure 2. Statistical results of $\triangle \mathrm{PWV}$ and PM10 at PTSV ((a) standard deviation (STD) statistics, (b) mean (MEAN) statistics, (c) maximum (MAX) statistics of PTSV). 

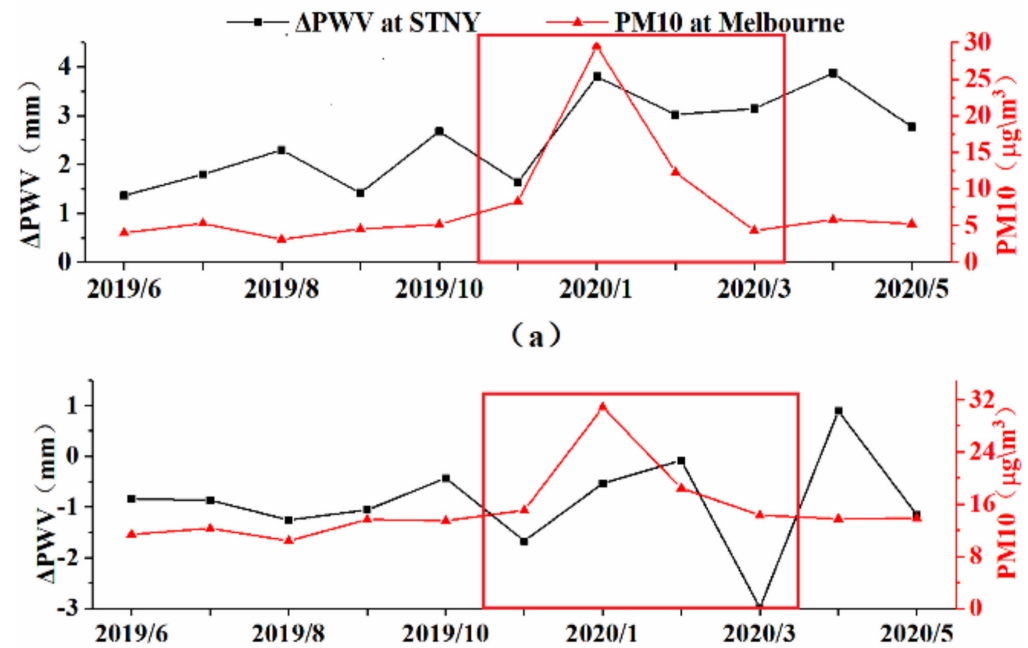

(b)

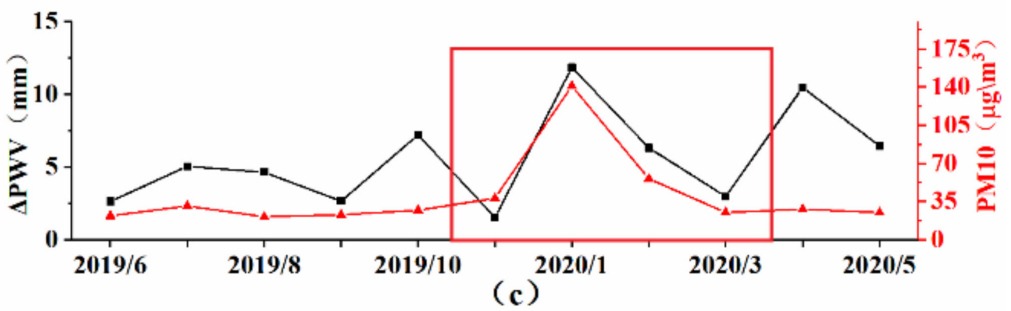

Figure 3. Statistical results of $\triangle \mathrm{PWV}$ and PM10 at STNY ((a) STD statistics, (b) MEAN statistics, (c) MAX statistics of STNY).

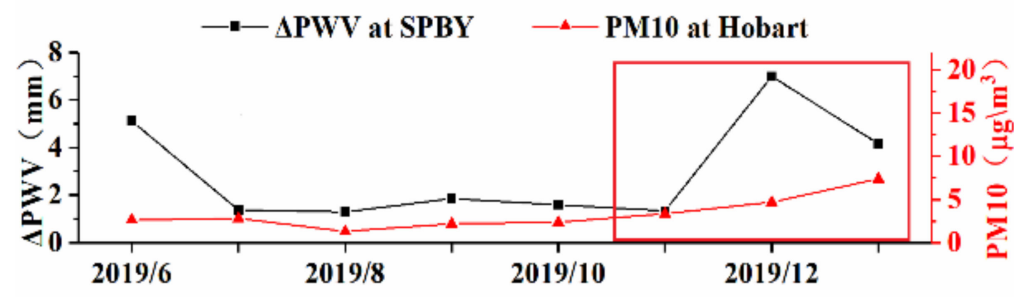

(a)
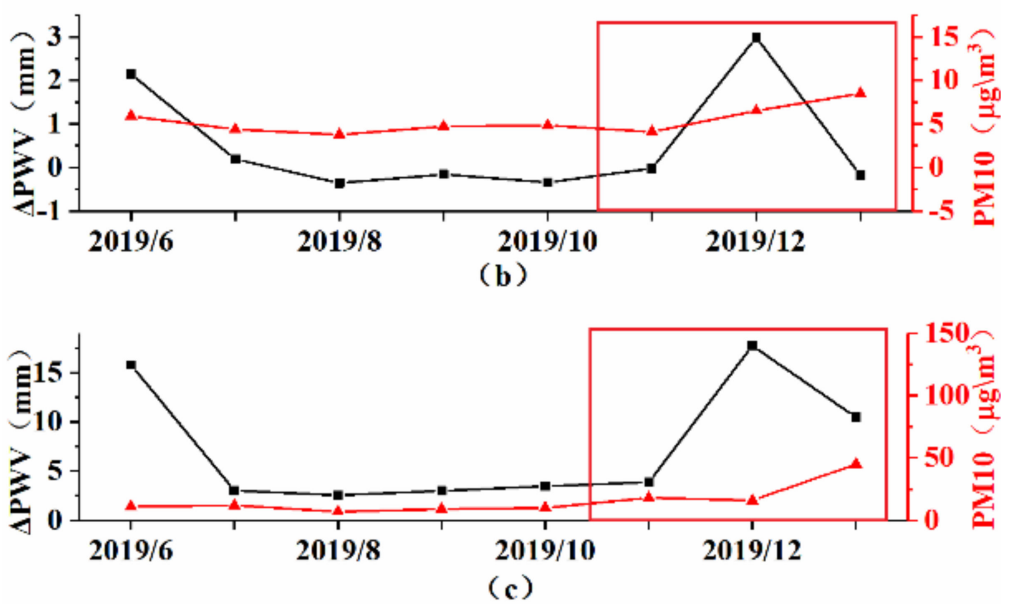

Figure 4. Statistical results of $\triangle \mathrm{PWV}$ and PM10 at SPBY ((a) STD statistics, (b) MEAN statistics, (c) MAX statistics of SPBY). 

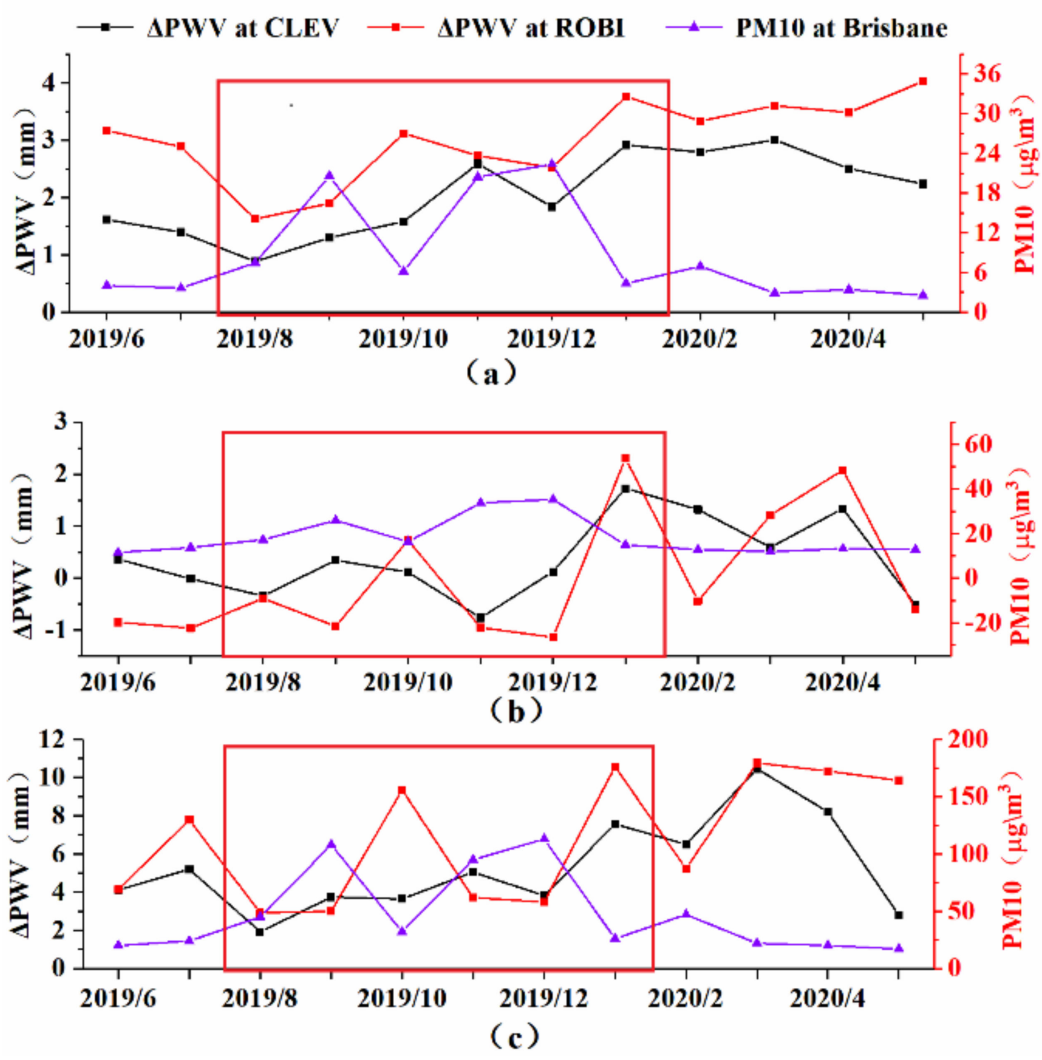

Figure 5. Statistical results of $\triangle \mathrm{PWV}$ and PM10 at CLEV and ROBI ((a) STD statistics, (b) MEAN statistics, (c) MAX statistics of CLEV and ROBI).
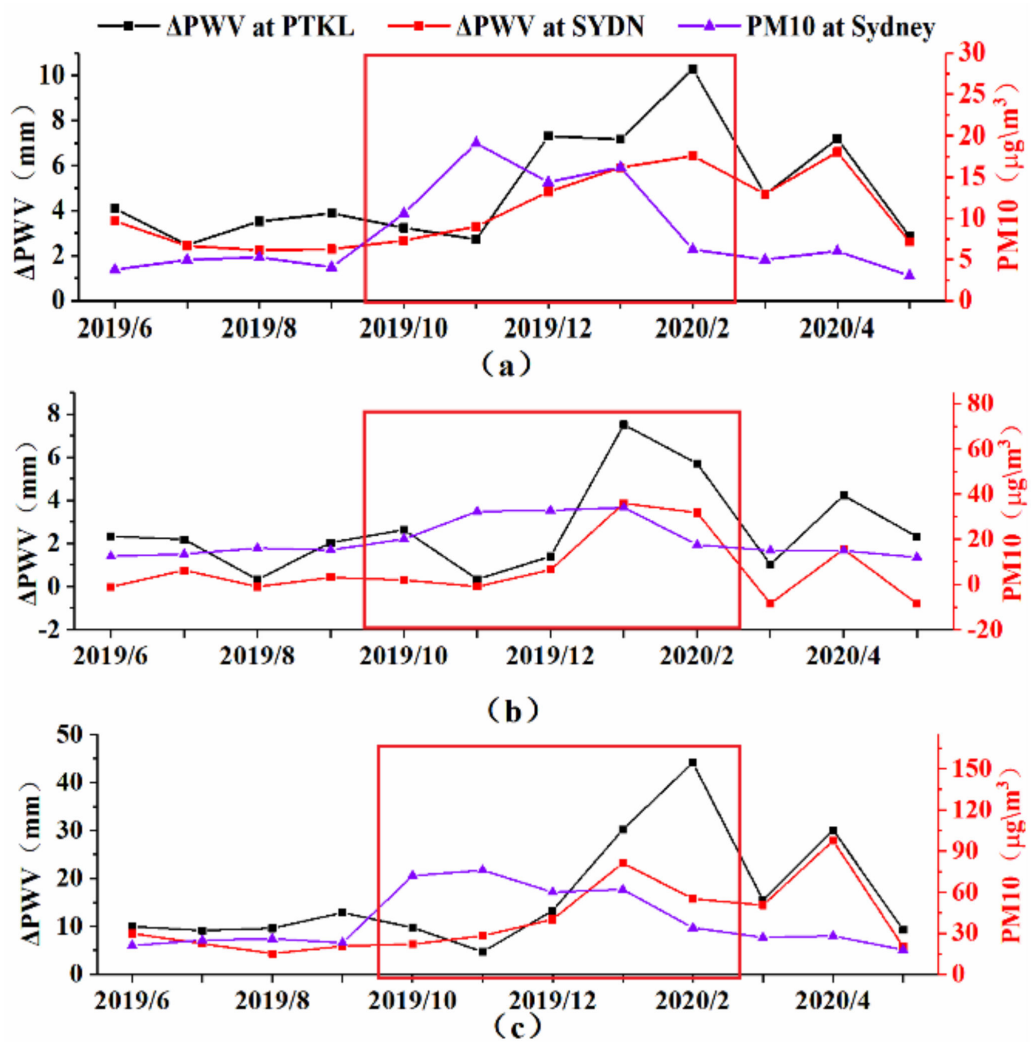

Figure 6. Statistical results of $\triangle \mathrm{PWV}$ and PM10 at PTKL and SYDN ((a) STD statistics, (b) MEAN statistics, (c) MAX statistics of PTKL and SYDN). 
It can be seen from Table 4 and Figure 2 that $\triangle \mathrm{PWV}$ and PM10 at the PTSV station show the same change pattern. The STD, MEAN, and MAX of $\triangle P W V$ and PM10 are all largest during the forest fire, and the STD, MEAN, and MAX of $\triangle P W V$ and PM10 before the forest fire are smaller than those after the forest fire.

Figure 2 shows that before the forest fire, the STD, MEAN, and MAX of $\triangle P W V$ and PM10 are small with relatively smooth fluctuations. During the forest fires, $\triangle \mathrm{PWV}$ and PM10 both have a sharp upward trend, and the trend of change is large. After the fire, PM10 decreases and gradually returns to stability. $\triangle \mathrm{PWV}$ is still large and the fluctuation is obvious. Before and during the fire, the trend of $\triangle \mathrm{PWV}$ is similar to that of PM10.

The PTSV station has a Mediterranean climate, alternatingly controlled by westerly winds and subtropical high pressure. Before the fire, $\triangle \mathrm{PWV}$ and PM10 show approximately the same change pattern, with smaller values and less fluctuation. During the fire, $\Delta P W V$ and PM10 show an increasing trend. Fires occur in the summer, in Mediterranean climates where rainfall is less. Therefore, $\triangle \mathrm{PWV}$ is less affected by precipitation. Forest fires lead to an increase in PM10 in air pollutants, leading to an increase in $\triangle \mathrm{PWV}$ affected by particulate matter. $\triangle \mathrm{PWV}$ is similar to PM10 before and during the fire. This is due to the influence of PM10 on $\triangle \mathrm{PWV}$ in case of forest fire. After the fire, PM10 decreases because the air quality monitoring station can only monitor the particulate pollutants on the surface, but it is difficult to monitor the particulate pollutants in the upper air. $\triangle \mathrm{PWV}$ remains large and varies dramatically after the fire, caused by particle stagnation in the environment. Therefore, it is feasible to use $\triangle \mathrm{PWV}$ to study particulate matter pollution from fires.

It can be seen from Table 4 and Figure 3 that $\triangle$ PWV and PM10 at the STNY station show the same change pattern before and during the forest fire. The STD and MEAN of $\triangle \mathrm{PWV}$ are small before the fire and largest after the fire. The MAX of $\triangle \mathrm{PWV}$ at STNY is largest during the fire and smallest before the fire. The STD, MEAN, and MAX of PM10 are all largest during the forest fire, and smaller before the forest fire than after.

Figure 3 shows that $\triangle \mathrm{PWV}$ and PM10 show the same change pattern before the fire. The STD, MEAN, and MAX of $\triangle \mathrm{PWV}$ and PM10 are all small with small fluctuations. During the fire, $\triangle \mathrm{PWV}$ and PM10 both have a sharp upward trend with relatively large values. After the fire, PM10 decreases and gradually returns to stability. $\triangle \mathrm{PWV}$ is still large with obvious fluctuation. Before and during the fire, the trend of $\triangle \mathrm{PWV}$ is similar to that of PM10.

The STNY station has a temperate marine climate, which is influenced by westerly winds at midlatitudes and is humid all year round. Before the fire, $\triangle \mathrm{PWV}$ and PM10 show approximately the same change pattern, with smaller values and less fluctuation. During the fire, $\triangle \mathrm{PWV}$ and PM10 show an increasing trend. Fires break out in the summer, in temperate marine climates where it is humid all year round. Therefore, $\triangle \mathrm{PWV}$ is less affected by precipitation. Forest fires lead to an increase in PM10 in air pollutants, leading to an increase in $\triangle \mathrm{PWV}$ affected by particulate matter. $\triangle \mathrm{PWV}$ is similar to PM10 before and during the fire. This is due to the fact that $\triangle \mathrm{PWV}$ is affected by PM10 when fires occur. After the fire, PM10 decreases because the air quality monitoring station can only monitor the particulate pollutants on the surface, and it is difficult to monitor particulate pollutants in the upper air. $\triangle \mathrm{PWV}$ remains large and varies dramatically after the fire caused by particle stagnation in the environment. Therefore, it is feasible to use $\triangle \mathrm{PWV}$ to study particulate matter pollution from fires.

It can be seen from Table 4 and Figure 4 that $\triangle \mathrm{PWV}$ and PM10 at the SPBY station show the same change pattern. The STD, MEAN, and MAX of $\triangle P W V$ and PM10 are all largest during the forest fire.

Figure 4 shows that before the fire, PM10 and $\triangle \mathrm{PWV}$ show the same change pattern. The STD, MEAN, and MAX of PM10 and $\triangle \mathrm{PWV}$ are small with relatively smooth fluctuations. During the fire, both $\triangle \mathrm{PWV}$ and PM10 show a sharp upward trend.

The SPBY station also has a temperate marine climate. Before the fire, $\triangle \mathrm{PWV}$ and PM10 show approximately the same change pattern, with smaller values and less fluctuation. During the fire, $\triangle \mathrm{PWV}$ and PM10 also have a sharp rise and a large change trend. Fires 
occur in the summer, in temperate marine climates where it is humid all year round. Therefore, $\triangle \mathrm{PWV}$ is less affected by precipitation. Forest fires lead to an increase in PM10 in air pollutants, leading to an increase in $\triangle \mathrm{PWV}$ affected by particulate matter. $\triangle \mathrm{PWV}$ is similar to PM10 before and during the fire. This is due to the fact that $\triangle \mathrm{PWV}$ is affected by PM10 when fires occur.

It can be seen from Table 4 and Figure 5 that $\triangle P W V$ and PM10 at CLEV and ROBI show different change patterns. During the fire, the STD, MEAN, and MAX of $\triangle \mathrm{PWV}$ are lower than those before the fire at CLEV and ROBI. The STD, MEAN, and MAX of $\triangle P W V$ are largest after the fire. The STD, MEAN, and MAX of PM10 at CLEV and ROBI are largest during the forest fire. Before the fire, the STD, MEAN, and MAX of PM10 are smaller than those after the fire.

Figure 5 shows that $\triangle \mathrm{PWV}$ and PM10 at CLEV and ROBI show different change patterns. The STD, MEAN, and MAX of PM10 are small with less fluctuations before and after the fire, and are largest when the fire occurs. In Figure 5a STD statistics, $\triangle P W V$ s at CLEV and ROBI are small before the fire and gradually increase during the fire. After the fire, $\triangle \mathrm{PWV}$ is larger and more stable. In Figure 5b MEAN statistics, $\triangle \mathrm{PWV}$ s at CLEV and ROBI show an upward trend during the forest fire. After the fire, $\triangle P W V$ is larger and the fluctuation is large. In Figure 5c MAX statistics, when the fire occurs at CLEV and ROBI, $\triangle \mathrm{PWV}$ fluctuates largely and shows an upward trend. $\triangle \mathrm{PWVs}$ at CLEV and ROBI are not similar to PM10.

CLEV and ROBI have a humid subtropical climate. $\triangle \mathrm{PWV}$ at CLEV and ROBI show different change trends with PM10 before and during the fire. The fact that CLEV and ROBI are located at the low latitude with more precipitation and humidity all year round can have a greater impact on PWV [25]. During the fire in the spring and summer, the southeast monsoon prevails, and the fire area is located in the northwest direction. However, the two stations are located on the coastal area on the northern edge of the Great Dividing Range, which is significantly affected by the difference in thermal properties between land and sea. This may be the reason that $\triangle \mathrm{PWV}$ during the fire does not increase with PM10 affected by the Great Dividing Range. Therefore, natural factors such as precipitation, topography, and climate cast a large influence on $\triangle \mathrm{PWV}$. These factors cause $\triangle \mathrm{PWV}$ to be different from PM10 during the fire. Since the fire occurs in the northwest and burns in a large area, particulate matter would have long-term stagnation in the air. The northwest monsoon blows in the winter, which causes $\triangle \mathrm{PWV}$ to fluctuate violently after the fire.

It can be seen from Table 4 and Figure 6 that before the fire, $\triangle \mathrm{PWV}$ and PM10 at PTKL and SYDN show the same change pattern. During the fire, the STD, MEAN, and MAX of $\triangle \mathrm{PWV}$ at PTKL are largest. After the fire, they are larger than before the fire. The STD and MAX of $\triangle \mathrm{PWV}$ at SYDN are smallest before the fire and largest after the fire. The MEAN of $\triangle \mathrm{PWV}$ at SYDN is largest during the fire. The STD, MEAN, and MAX of PM10 at PTKL and SYDN are largest during the fire, and after the fire, PM10 is slightly larger than before the fire.

Figure 6 shows that before the forest fire, the STD, MEAN, and MAX of PM10 and $\triangle \mathrm{PWV}$ are small and the fluctuations are relatively smooth. When the fire breaks out, $\triangle \mathrm{PWV}$ does not increase immediately with PM10 until December. After the fire, PM10 decreases and gradually returns to stability, but $\triangle \mathrm{PWV}$ is still large and fluctuates greatly.

PTKL and SYDN have a humid subtropical climate. Before the fire, $\triangle \mathrm{PWV}$ is similar to PM10, both stable and small. When the fire breaks out in October, PM10 rises sharply, but $\triangle$ PWV does not rise until December. SYDN and PTKL are located on the eastern windward slope of the Great Dividing Range. During the fire, it is close to summer, mainly affected by the southeast monsoon, and from October to November, forest fires occur in the northwest of the stations. Therefore, particulate matter is blocked by the Great Dividing Range, causing the delay of $\triangle \mathrm{PWV}$. After the fire, the study area are affected by the northwest monsoon in autumn. Affected by the climate, the particulate matters are in the upper air. $\triangle \mathrm{PWV}$ does not drop immediately and remains large. 


\subsection{Correlation Analysis of $\triangle P W V$ and $P M 10$}

By analyzing the MAX, STD, and MEAN of PM10 and $\triangle \mathrm{PWV}$ of seven GNSS stations, the feasibility of forest fire monitoring based on the GNSS is verified. According to the analysis in Section 3.2, the $\triangle \mathrm{PWV}$ change trends of PTSV (Mediterranean climate), STNY (temperate marine climate), and SPBY (temperate marine climate) are similar to those of PM10. However, the GNSS data of SPBY is insufficient. Therefore, PTSV and STNY are selected as examples for analysis.

Forest fire will produce a large amount of PM10, and with the change of fire, the contents of PM10 will change dramatically. STD can represent those changes. STD is calculated every 15 days of the $\triangle \mathrm{PWV}$ time series, and the time series of moving STD is formed by moving backward once a day. The same operation is also made on the PM10 time series. The correlation between the two sequences is analyzed with the results listed in Table 5.

Table 5. Correlation coefficient statistics between the 15-day moving STD time series of $\triangle \mathrm{PWV}$ and PM10 at PTSV and STNY. The format of Time is: month/year.

\begin{tabular}{ccccc}
\hline Name & Index & Before & During & After \\
\hline \multirow{2}{*}{ PTSV } & Time & $6 / 19-11 / 19$ & $12 / 19-2 / 20$ & $3 / 20-5 / 20$ \\
& Correlation & 0.439 & 0.574 & -0.492 \\
STNY & Time & $6 / 19-10 / 19$ & $11 / 19-3 / 20$ & $4 / 20-5 / 20$ \\
& Correlation & -0.285 & 0.720 & 0.779 \\
\hline
\end{tabular}

Statistics show that the correlation coefficient between the 15-day moving STD time series of $\triangle \mathrm{PWV}$ and PM10 after the fire breaks out at PTSV and STNY is significantly higher than that before the fire. A fire will produce a large amount of PM10. As the fire changes, PM10 will also change. As mentioned in Section 1, $\triangle \mathrm{PWV}$ is caused by particles in the air. Therefore, the changes of PWV and PM10 are similar, and the correlation is enhanced, which also demonstrates the feasibility of monitoring forest fires based on $\triangle \mathrm{PWV}$ obtained by the GNSS.

\section{Discussion}

In Section 3, it is found that PM10 and PM2.5 have a high correlation, and their sources are similar [48]. Before and during the fire, it is found that $\triangle \mathrm{PWV}$ is similar to PM10 at PTSV (Mediterranean climate) [36], STNY (temperate marine climate), and SPBY (temperate marine climate) [38]. $\triangle \mathrm{PWV}$ and PM10 are small with less fluctuations before the fire. When the fire breaks out, $\triangle \mathrm{PWV}$ and PM10 rise sharply with relatively large values. After the fire, PM10 drops sharply and becomes small. $\triangle \mathrm{PWV}$ is still large with drastic changes. $\triangle \mathrm{PWV}$ after the fire is inconsistent with PM10, mainly since PM10 is monitored on the surface of the ground by the air quality monitoring station, and the particulate matter in the upper air is difficult to monitor [49]. The wide range and long duration of the fire cause the particulate matter to stay in the air for a long time, which demonstrates the feasibility of monitoring forest fires with GNSS technique in climate conditions with regular precipitation. By comparing the correlation coefficient of the moving STD time series of $\triangle \mathrm{PWV}$ and PM10 at PTSV and STNY, $\triangle \mathrm{PWV}$ is closely related to particulate matter, proving that $\triangle \mathrm{PWV}$ is feasible for monitoring forest fires.

Before the fire, $\triangle \mathrm{PWV}$ and PM10 are stable and relatively small at SYDN and PTKL (humid subtropical climate). When the fire occurs, $\triangle \mathrm{PWV}$ and PM10 increase rapidly. After the fire, PM10 becomes small, while $\triangle \mathrm{PWV}$ is still large due to particulate matter in the air. $\triangle \mathrm{PWVs}$ at ROBI and CLEV (humid subtropical climate) do not appear to be similar to PM10. The main reason is that the fire occurs in the spring and summer with more precipitation and the southeast monsoon [36]. The fire is located on the northwest affected by the Great Dividing Range, causing sharp fluctuation of $\triangle \mathrm{PWV}$.

Therefore, before and during the fire, $\triangle \mathrm{PWV}$ is similar to PM10, so $\triangle \mathrm{PWV}$ can be used to monitor the fire. After the fire, the stagnation of particulate matter will affect $\Delta \mathrm{PWV}$, 
which makes it different from PM10. The long-term stagnation of particulate matter can cause lasting environmental damage.

\section{Conclusions}

The conclusions are as follows:

(1) In climate conditions with regular precipitation, such as Mediterranean climate and temperate marine climate, it is feasible to use $\triangle \mathrm{PWV}$ to monitor forest fires. The performance is very stable before and during the fire. After the fire, it is impossible to monitor the forest fire due to particulate matter stagnation in the air.

(2) In climatic conditions with irregular precipitation, such as humid subtropical climate, due to more precipitation in the rainy season and strong transpiration caused by temperature rise, $\triangle \mathrm{PWV}$ will be severely affected.

(3) When the fire occurs, much PM10 will be produced, and the correlation between $\triangle \mathrm{PWV}$ and PM10 will increase. Therefore, $\triangle \mathrm{PWV}$ can be used to study the pollution caused by PM10/PM2.5 from fire. After the fire, $\triangle \mathrm{PWV}$ can also reflect the stagnation of particulate matter, so $\triangle \mathrm{PWV}$ can be used to study particulate matter stagnation in the environment in future work.

(4) $\triangle \mathrm{PWV}$ will be affected by climate, precipitation, wind direction, and other environment factors, which demonstrates that monitoring forest fires needs further research in climate conditions with irregular precipitation using GNSS technique.

Author Contributions: J.G.: conceptualization, methodology, funding acquisition. R.H.: data curation, writing — original draft preparation, software. Maosheng Zhou: validation, writing—reviewing and editing, investigation. X.J.: software, validation. C.L.: supervision. X.L.: supervision. H.G.: reviewing and editing. All authors have read and agreed to the published version of the manuscript.

Funding: This work is supported by the National Natural Science Foundation of China (Grant Nos. 41774001, 41374009), SDUST Research Fund (Grant No. 2014TDJH101), State Key Laboratory of Tropical Oceanography, South China Institute of Oceanology, Chinese Academy of Sciences (Project No. LTO2017), and Shandong Province Youth Innovation and Technology Program (Project No. 2019KJN009).

Informed Consent Statement: Not applicable.

Data Availability Statement: The GNSS observation data used in our work can be freely accessed at https:/ / www.sonel.org/. The PWV data are obtained from http://weather.uwyo.edu/upperair/ sounding.html. The air quality monitoring data are obtained from https://aqicn.org/ data- platform/register/. The forest fire information is obtained from https://firms.modaps.eosdis.nasa.gov/ map/.

Acknowledgments: We are very grateful to SONEL for providing the GPS data. We thank Massachusetts Institute of Technology (MIT), Scripps Institution of Oceanography (SIO), and Harvard University for providing the GAMIT/GLOBK software.

Conflicts of Interest: The authors declare no conflicts interest.

\section{References}

1. Adams, M.A.; Shadmanroodposhti, M.; Neumann, M. Causes and consequences of Eastern Australia's 2019-20 season of mega-fires: A broader perspective. Glob. Change Biol. 2020, 26, 3756-3758. [CrossRef]

2. Proloy, D.; Hamid, M.; Peyman, A.; Anthony, S.K.; Johanna, E.; David, K.; Ashish, S. Causes of the Widespread 2019-2020 Australian Bushfire Season. Earth's Future 2020, 8, e2020EF001671.

3. O'Loughlin, C.; Jones, S.C.; Jenkins, M.; Gordon, C.E. The effects of inter-fire interval on flora-fauna interactions in a sub-alpine landscape. For. Ecol. Manag. 2020, 473, 118316. [CrossRef]

4. Kolář, T.; Kusbach, A.; Čermák, P.; Štěrba, T.; Batkhuu, E.; Rybníček, M. Climate and wildfire effects on radial growth of Pinus sylvestris in the Khan Khentii Mountains, north-central Mongolia. J. Arid Environ. 2020, 182, 104223. [CrossRef]

5. Guo, X.Y.; Zhang, H.Y.; Wang, Y.Q.; Zhao, J.J.; Zhang, Z.X. The driving factors and their interactions of fire occurrence in Greater Khingan Mountains, China. J. Mt. Sci. 2020, 17, 2674-2690. [CrossRef]

6. Alkhatib, A.A. A review on forest fire detection techniques. Int. J. Distrib. Sens. Netw. 2014, 10, 103-110. [CrossRef] 
7. Yuan, C.; Zhang, Y.; Liu, Z. A survey on technologies for automatic forest fire monitoring, detection, and fighting using unmanned aerial vehicles and remote sensing techniques. Can. J. For. Res. 2015, 45, 783-792. [CrossRef]

8. Sharma, A.; Singh, P.K.; Kumar, Y. An integrated fire detection system using IoT and image processing technique for smart cities. Sustain. Cities Soc. 2020, 61, 102332. [CrossRef]

9. Zhang, F.; Zhao, P.; Xu, S.; Wu, Y.; Yang, X.; Zhang, Y. Integrating multiple factors to optimize watchtower deployment for wildfire detection. Sci. Total Environ. 2020, 737, 139561. [CrossRef]

10. Yin, S.; Wang, X.; Guo, M.; Santoso, H.; Guan, H. The abnormal change of air quality and air pollutants induced by the forest fire in Sumatra and Borneo in 2015. Atmos. Res. 2020, 243, 105027. [CrossRef]

11. Melo, A.M.; Reis, C.R.; Martins, B.F.; Penido, T.M.A.; Rodriguez, L.C.E.; Gorgens, E.B. Monitoring the understory in eucalyptus plantations using airborne laser scanning. Sci. Agric. 2020, 78, 1-6. [CrossRef]

12. Bowman, D.; Williamson, G.; Yebra, M.; Lizundia-Loiola, J.; Pettinari, M.L.; Shah, S.; Bradstock, R.; Chuvieco, E. Wildfires: Australia needs national monitoring agency. Nature 2020, 584, 188-191. [CrossRef] [PubMed]

13. Barmpoutis, P.; Papaioannou, P.; Dimitropoulos, K. A review on early forest fire detection systems using optical remote sensing. Sensors 2020, 20, 6442. [CrossRef] [PubMed]

14. Yao, L.; Lu, N.; Yue, X.; Du, J.; Yang, C. Comparison of hourly PM2.5 observations between urban and suburban areas in Beijing, China. Int. J. Environ. Res. Public Health 2015, 12, 12264-12276. [CrossRef]

15. Kiser, D.; Metcalf, W.; Elhanan, G.; Schnieder, B.; Schlauch, K.; Joros, A.; Petersen, C.; Grzymski, J. Particulate matter and emergency visits for asthma: A time-series study of their association in the presence and absence of wildfire smoke in Reno, Nevada, 2013-2018. Environ. Health 2020, 19, 1-12. [CrossRef]

16. Augusto, S.; Ratola, N.; Tarín-Carrasco, P.; Jiménez-Guerrero, P.; Turco, M.; Schuhmacher, M.; Costa, S.; Teixeira, J.P.; Costa, C. Population exposure to particulate-matter and related mortality due to the Portuguese wildfires in October 2017 driven by storm Ophelia. Environ. Int. 2020, 144, 106056. [CrossRef]

17. Sánchez-Balseca, J.; Pérez-Foguet, A. Modelling hourly spatio-temporal PM2.5 concentration in wildfire scenarios using dynamic linear models. Atmos. Res. 2020, 242, 104999. [CrossRef]

18. Guo, L.; Ma, Y.; Tigabu, M.; Guo, X.; Zheng, W.; Guo, F. Emission of atmospheric pollutants during forest fire in boreal region of China. Environ. Pollut. 2020, 264, 114709. [CrossRef]

19. Guo, M.; Zhang, H.; Xia, P. A method for predicting short-time changes in fine particulate matter (PM2.5) mass concentration based on the global navigation satellite system zenith tropospheric delay. Meteorol. Appl. 2020, 27, e1866. [CrossRef]

20. Wen, H.; Dang, Y.; Li, L. Short-Term PM2.5 concentration prediction by combining GNSS and meteorological factors. IEEE Access 2020, 8, 115202-115216. [CrossRef]

21. Vaquero-Martínez, J.; Antón, M.; Román, R.; Cachorro, V.E.; Wang, H.; González Abad, G.; Ritter, C. Water vapor satellite products in the European Arctic: An inter-comparison against GNSS data. Sci. Total Environ. 2020, 741, 140335. [CrossRef] [PubMed]

22. Colman, R. A comparison of climate feedbacks in general circulation models. Clim. Dyn. 2003, 20, 865-873. [CrossRef]

23. Zhang, K.; Manning, T.; Wu, S.; Rohm, W.; Silcock, D.; Choy, S. Capturing the signature of severe weather events in Australia using GPS measurements. IEEE J. Sel. Top. Appl. Earth Obs. Remote Sens. 2015, 8, 1839-1847. [CrossRef]

24. Zhao, Q.; Ma, X.; Yao, W.; Liu, Y.; Yao, Y. Anomaly variation of vegetation and its influencing factors in mainland China during ENSO period. IEEE Access 2020, 8, 721-734. [CrossRef]

25. Zhao, Q.; Yao, Y.; Yao, W. Capturing the signature of heavy rainfall events using the 2-d-/4-d water vapour information derived from GNSS measurement in Hong Kong. Ann. Geophys. Discuss. 2018, 76, 1-25.

26. Holloway, C.E.; Neelin, J.D. Temporal relations of column water vapor and tropical precipitation. J. Atmos. Sci. 2010, 67, 1091-1105. [CrossRef]

27. Wang, Z.; Zhou, X.; Liu, Y.; Zhou, D.; Zhang, H.; Sun, W. Precipitable water vapor characterization in the coastal regions of China based on ground-based GPS. Adv. Space Res. 2017, 60, 2368-2378. [CrossRef]

28. Zhao, Q.; Yao, Y.; Yao, W.; Zhang, S. GNSS-derived PWV and comparison with radiosonde and ECMWF ERA-Interim data over mainland China. J. Atmos. Solar Terr. Phys. 2019, 182, 85-92. [CrossRef]

29. Ohtani, R.; Naito, I. Comparisons of GPS-derived precipitable water vapors with radiosonde observations in Japan. J. Geophys. Res. Atmos. 2020, 105, 26917. [CrossRef]

30. Vázquez, B.G.E.; Grejner-Brzezinska, D.A. GPS-PWV estimation and validation with radiosonde data and numerical weather prediction model in Antarctica. GPS Solut. 2013, 17, 29-39. [CrossRef]

31. Vaquero-Martínez, J.; Antón, M.; Ortiz de Galisteo, J.P.; Román, R.; Cachorro, V.E.; Mateos, D. Comparison of integrated water vapor from GNSS and radiosounding at four GRUAN stations. Sci. Total Environ. 2019, 648, 1639-1648. [CrossRef] [PubMed]

32. Basili, P.; Bonafoni, S.; Mattioli, V.; Ciotti, P.; Marzano, F.S.; Pierdicca, N.; Pulvirenti, L.; D’Auria, G. Mapping of precipitable water vapour by integrating measurements of ground-based GPS receivers and satellite-based microwave radiometers. Int. Geosci. Remote Sens. Symp. 2002, 2, 1275-1276.

33. Manandhar, S.; Lee, Y.H.; Dev, S. GPS Derived PWV for Rainfall Monitoring. In Proceedings of the International Geoscience and Remote Sensing Symposium (IGARSS), Beijing, China, 10-15 July 2016; pp. 2170-2173.

34. Roy, D.P.; Boschetti, L.; Justice, C.O.; Ju, J. The collection 5 MODIS burned area product-Global evaluation by comparison with the MODIS active fire product. Remote Sens. Environ. 2008, 112, 3690-3707. [CrossRef] 
35. Bowman, D.M.J.S.; Williamson, G.J.; Price, O.F.; Ndalila, M.N.; Bradstock, R.A. Australian forests, megafires and the risk of dwindling carbon stocks. Plant Cell Environ. 2020, 13916, 1-37. [CrossRef]

36. Knighton, J.; Vijay, V.; Palmer, M. Alignment of tree phenology and climate seasonality influences the runoff response to forest cover loss. Environ. Res. Lett. 2020, 15, 104051. [CrossRef]

37. Hernandez-Ochoa, I.M.; Asseng, S. Cropping systems and climate change in humid subtropical environments. Agronomy 2018, 8, 19. [CrossRef]

38. Zarco-Perello, S.; Carroll, G.; Vanderklift, M.; Holmes, T.; Langlois, T.J.; Wernberg, T. Range-extending tropical herbivores increase diversity, intensity and extent of herbivory functions in temperate marine ecosystems. Funct. Ecol. 2020, 34, 2411-2421. [CrossRef]

39. Sultana, J.; Recknagel, F.; Nguyen, H.H. Species-specific macroinvertebrate responses to climate and land use scenarios in a Mediterranean catchment revealed by an integrated modelling approach. Ecol. Indic. 2020, 118, 106766. [CrossRef]

40. Zhou, M.S.; Liu, X.; Yuan, J.J.; Jin, X.; Niu, Y.P.; Guo, J.Y.; Gao, H. Seasonal variation of GPS-derived the principal ocean tidal constituents' loading displacement parameters based on moving harmonic analysis in Hong Kong. Remote Sens. 2021, 13, 279. [CrossRef]

41. Jin, S.G.; Luo, O.; Ren, C. Effects of physical correlations on long-distance GPS positioning and zenith tropospheric delay estimates. Adv. Space Res. 2010, 46, 190-195. [CrossRef]

42. Liu, Z.; Li, Y.; Li, F.; Guo, J. Estimation and Evaluation of the Precipitable Water Vapor from GNSS PPP in Asia Region. In Lecture Notes in Electrical Engineering, Proceedings of the China Satellite Navigation Conference (CSNC), Shanghai, China, 23-25 May 2017; Sun, J., Liu, J., Yang, Y., Fan, S., Yu, W., Eds.; Springer: Singapore, 2017; pp. 85-95.

43. Zhou, M.S.; Guo, J.Y.; Liu, X.; Shen, Y.; Zhao, C.M. Crustal movement derived by GNSS technique considering common mode error with MSSA. Adv. Space Res. 2020, 66, 1819-1828. [CrossRef]

44. Saastamoinen, J. Atmospheric correction for the troposphere and stratosphere in radio ranging satellites. Use Artif. Satell. Geod. 1972, 15, 247-251.

45. Bevis, M.; Businger, S.; Herring, T.A.; Rocken, C.; Anthes, R.A.; Ware, R.H. GPS meteorology: Remote sensing of atmospheric water vapor using the global positioning system. J. Geophys. Res. Atmos. 1992, 97, 15787-15801. [CrossRef]

46. Bevis, M.; Businger, S.; Chiswell, S.; Herring, T.A.; Randolph, H.W. GPS meteorology: Mapping zenith wet delays onto precipitable water. J. Appl. Meteorol. 1994, 33, 379-386. [CrossRef]

47. Zhang, Q.; Ye, J.; Zhang, S.; Han, F. Precipitable water vapor retrieval and analysis by multiple data sources: Ground-based GNSS, radio occultation, radiosonde, microwave satellite, and NWP reanalysis data. J. Sens. 2018, 2018, 1-13. [CrossRef]

48. Madureira, J.; Slezakova, K.; Costa, C.; Pereira, M.C.; Teixeira, J.P. Assessment of indoor air exposure among newborns and their mothers: Levels and sources of PM10, PM2.5 and ultrafine particles at 65 home environments. Environ. Pollut. 2020, 264, 114746. [CrossRef]

49. He, H.; Lu, W. Comparison of three prediction strategies within PM 2.5 and PM 10 monitoring networks. Atmos. Pollut. Res. 2020, 11, 590-597. [CrossRef] 